Journal of East Asian Cultures 2021/1: 159-171

DOI: $10.38144 /$ TKT.2021.1.10

https://orcid.org/0000-0002-5198-6768

heruyi@student.elte.hu

HE RUYI

\title{
Some Characteristic Features of Family Structure in the Old Uighur Societies (as Reflected in Contractual Documents)
}

\section{Introduction}

The Old Uighur (回鹘) is one of the main ethnic origins of the present Uighur and Yughur. ${ }^{1}$ In 744, Old Uighur people established the Uighur Khanate in the Mongol Steppe, and the empire continued until 840. After that, the Old Uighurs migrated to the west and south. Some of them also migrated to the Qocho area. During the Yuan dynasty $\left(13^{\text {th }}-14^{\text {th }}\right.$ century), they still lived in this area and integrated with many other ethnic groups. They used Old Uighur script, which mainly prevailed between the $9^{\text {th }}$ and $15^{\text {th }}$ centuries. Since the end of $19^{\text {th }}$ century and the beginning of $20^{\text {th }}$ century, many contractual documents recorded in Old Uighur script have been unearthed in the Turpan area of Xinjiang. These documents are important first-hand sources reflecting the culture, customs, religion, economy, social system, family life and other aspects of the Old Uighurs.

Old Uighur documents are profoundly studied. Most of the research focuses on the philological studies of the text, such as transliteration, interpretation and translation. ${ }^{2}$ In addition, some scholars have also done research from the perspective of history, economics and culture. ${ }^{3}$ As a direct reflection of the economic and social life of the Old Uighurs at that time, contractual documents need to be studied further from various perspectives. Family is clearly an important unit in this social structure. In different historical periods and different social and cultural backgrounds, the family structure and characteristics of each ethnic group

${ }^{1}$ This opinion is accepted by most Chinese scholars, while some European scholars have a different view.

2 Radloff 1928; Ligeti 1973; Zieme 1974; Yamada 1993; Li 1996; Liu 2000; Geng 2006; Li 2012.

${ }^{3}$ Vernadsky 1936; Gabain 1973; Zieme 1976; Zhang 1983; Yang 1990. 
manifest their own differences. There has been much previous research in this field and the selection of research for this paper has been of very great interest to the author of this paper. On the basis that Old Uighur contractual documents shed light on some of the characteristics of family structure in the Old Uighur societies, previous studies have been selected on the basis of the inclusion of such contracts. The main source corpus comes from those collected by Nobuo Yamada 山田信夫 in "Sammlung Uigurischer Kontrakte" / Uiguru bun keiyaku bunsho shüsei ウイグル文契約文書集成 ${ }^{4}$ and is used to briefly introduce some features of family structures in the Old Uighur societies during Yuan dynasty.

The present paper explores the sources from the following aspects. Firstly, we briefly introduce the main types and formats of Old Uighur contractual documents, and the Old Uighur society in the $13^{\text {th }}-14^{\text {th }}$ century; next, we analyze the family structure of the Old Uighurs according to some contractual documents. In the following, we mainly discuss the status and male and female roles in the Old Uighur's family. Finally, we expound the phenomenon of selling and mortgaging relatives in the Old Uighur's society.

\section{The main types and formats of Old Uighur contractual documents}

There are about 400 Old Uighur contractual documents collected and published in many countries such as Germany, Britain, France, Russia, Japan, China and the United States. ${ }^{5}$ Most of them are from the period of Yuan Dynasty $\left(13^{\text {th }}-14^{\text {th }}\right.$ century), and are written in cursive script. Based on their content, they can be divided into sales contracts, loan contracts, lease contracts, exchange contracts, slave contracts and so on.

The structure and content of Old Uighur contractual documents follows below: ${ }^{6}$

1. borrowing date

2. names of the creditor and debtor ${ }^{7}$

3. list of borrowed objects and their amount

${ }^{4}$ Yamada (author), Oda et al. (eds) 1993.

5 Radloff 1928; Ramstedt 1969; Zieme 1974, 1977, 1980a, 1980b, 1992; Hamilton 1986; Yamada 1993; Li 1996, 2012; Geng 2006.

${ }^{6}$ The format of the Old Uighur loan contracts presented in this article have been based on Yamada 1965: 165.

${ }^{7}$ In Old Uighur contractual documents, the guarantor (baošin, taybaošïn) and the witness (tanuq) usually have specific terms, while the debtor and the creditor do not. They are usually expressed by the verb al- 'buy', sat- 'sell', bir- 'pay' and so on. For instance, (xxx) Altmï̌saq-qa

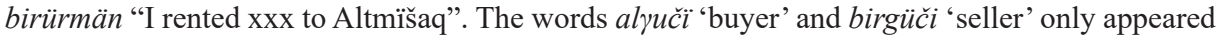
in a few documents. 
4. repayment date

5. repayment amount

6. additional repayment amount

7. the solution when the debtor cannot repay

8. names of witness (tanuq)

9. fingerprint of debtor and witness

10. writer $^{8}$

The Old Uighur Contractual documents are greatly influenced by Chinese contractual documents. ${ }^{9}$ To be more specific, the format, frame and main content of Old Uighur contractual documents are basically the same as that of Chinese contractual documents. In addition, Zhang and Cui (2017) pointed out that some appellations of the participants in Old Uighur contractual documents are transliterated words borrowed from Chinese such as baošin 保人 'guarantor', taybaošin 代保人 'substitute guarantor', tungsu 同取人 'co-debtor'. And some appellations are translations of Chinese words, such as birlä alyuči 同取人 'co-debtor', yügärüki tanuq 时见 'eyewitness on the spot'. ${ }^{10}$ To some extent, it shows that the Old Uighurs had been closely connected with the Chinese people in successive dynasties for a long time.

Most importantly, these different types of contractual documents reflected the social and economic life of the Old Uighurs at that time, and also reflected their family structure and characteristics.

\section{The Old Uighur society in the $13^{\text {th }}-14^{\text {th }}$ century}

During the $13^{\text {th }}-14^{\text {th }}$ century, the Old Uighur society in Qocho area was composed of people from various ethnic groups such as Old Uighurs, Mongolians, Chinese, Kipchaks, Sogdians, Arabs, Khitans and so on. In this period, the Old Uighurs were under the rule of the Mongols. This fact was reflected in some contractual documents (e.g. Sa11 ${ }^{11}$ ), for example, if the signers violated the terms of the contract, they had to pay separate fines to the Mongolian emperors and Mongolian princes.

${ }^{8}$ In Old Uighur contractual documents, the writer also doesn't have a specific term, it is expressed by verb biti- 'write', for example, xxx bitidim 'xxx wrote'.

9 Yamada 1965; Liu 2000.

${ }^{10}$ More details can be found in Zhang - Cui 2017.

11 The document number here refers to the serial number marked in Yamada, N (1993). 
In this period, the Old Uighurs mainly lived a settled agricultural life, ${ }^{12}$ as demonstrated by the many agreements for buying and selling fields and orchards. In addition, they also show that this horticulture and commerce was well-developed. The presence of altun 'gold', kümiš 'silver' and other currencies in precise units in contractual documents prove that commercial activities in the Old Uighur society had developed to a very mature level. There were also some textiles such as qunpu 'official cloth' and böz 'cotton cloth' which used instead of money as a medium for sale and exchange.

The phenomenon of trade in humans was another important characteristic of the Old Uighur society in this period. It began in Han Dynasty (202 BC-220 AD) and became more frequent in the Tang (618-907), Song (960-1279) and Yuan (1271-1368) dynasties. Consequently, the trade in humans in the Old Uighur society was considerable during this period, and the main groups that were bought and sold were slaves, children and women.

\section{Family structure in the Old Uighur society}

From the Old Uighur contractual documents, it can be seen that most civilian families adopted monogamy, and the type of family structure was the extended paternal family consisting of kin groups. The kinship system of Old Uighurs was inherited from the system of the Old Turkic period ( $6^{\text {th }}-7^{\text {th }}$ century), and was developed and diversified into a more detailed system by the Old Uighurs. Its kinship appellation was also more complex and systematic than in previous periods, and reflected a strict distinction between paternal and maternal relatives. The main kinship terminologies of Old Uighurs are as follow: ata, $a d a, b a b a$, qay 'father', ana, ög, uma 'mother', aqa, äci, bay 'elder brother',

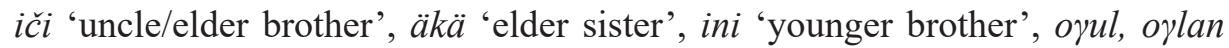
'son', qïz 'daughter', balïz, balïr, sinil 'younger sister', bäg 'husband', qadaš 'sibling', kiši, yutuz 'wife', yägän 'nephew', küdäg 'son-in-law', kälin 'daughter-in-law' ${ }^{13}$ As far as we know, the kinship terminology of the Old Uighurs has not been studied in a very detailed or comprehensive way. Nonetheless, there are some studies on individual kinship appellation, such as the study on the term yägän 'nephew' in Old Uighur contract. ${ }^{14}$

${ }_{12}$ A more detailed study of medieval Uighur society and history was conducted by Brose (2017). In addition, the material culture of the Old Uighurs was also studied in detail and systematically by Gabain (1973). Therefore, the present paper does not elaborate on these aspects.

13 Gabain 1973; Chen 1996.

${ }^{14}$ Liu - Kou 2006. 
The Old Uighur loan contracts show that the relationship between family members was very close, the blood relationship being especially important. Specifically, brothers lived together and shared property in the family. In general, there were several types of main participants in the Old Uighur loan contract, these were creditor, debtor, guarantor, eyewitness and writer. Among them, the guarantor was the main subject that we will discuss. An example of the above loan contracts in Old Uighur script follows below: ${ }^{15}$

Lo10:16

1. tonguz yil ikinti ay alti

2. otuz-qa manga šivsadu tutung-qa

3. küsmiš kärgäk bolup šinsun šäli-

4. -tä on stïr kümiš altïm onïnč

5. ay on yangïqa tägim-čä birür

6. -män birginčä yoq bar bolsar

7. -män inim ozmï̌ toyrïl köni

8. birșün tanuq arqaүun ïnal

9. tanuq sarï̀ toÿ̈ tanuq öküz

10. torril tanuq känt qay-a

11. tanuq arti ïnal bu tam- $\gamma$ a

12. biṣ-ning ikägününg ol män

13. šivsadu tutung ayïdïm bitidim

Translation:

"On February $26^{\text {th }}$, in the year of the pig, since I, Šivsadu Tutung, needed the silver, I borrowed ten stïr silver from Šinsun Säli, I give them back on time on

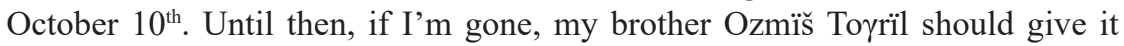
correctly.

Witness: Arqayun Ïnal,

Witness: Sarï Toyïn

Witness: Öküz Torrïl

Witness: Känt Qaya

Witness: Arti Înal

This seal belongs to us.

I, Šivsadu Tutung, wrote it after asking."

15 The document numbers mentioned in this paper refers to the number compiled by Yamada (1993) and the transcription of the Old Uighur text also adopts the transcription of Yamada (1993). The English translation is made by the author herself.

16 The original transcription, Japanese and German translation can be seen in Yamada (II, 1993: 92-93). 
This document gives clear information about the parties to the contract (creditor: S̈̈̈nsun Säli, debtor: Šivsadu Tutung), the date of its establishment (February 26 in the year of the pig $^{17}$ ), the date of repayment (October $10^{\text {th }}$ ), and information about the guarantor (debtor's brother Ozmï̌ Toyril), five eyewitnesses and writer. In the loan contract, the guarantor plays a very important role, which is to assume the responsibility for ensuring that the debt is repaid. When the debtor is unable to repay the debt, the guarantor will be liable for the debt. In most Old Uighur loan contracts, we can see statements like "birginčä yoq bar bolsar, män...birșün", indicating that if the debtor dies before he repays, the debt will be repaid by his guarantor. From the observation of 30 Old Uighur loan contracts, which were collected in Yamada's text corpus (1993), we found that in most contracts the debtor's guarantor is assumed by their family members such as brothers, parents, children, wives, and sisters, the distribution of guarantors are shown in the table below:

\begin{tabular}{|l|l|l|l|}
\hline \multicolumn{1}{|c|}{ guarantors } & \multicolumn{1}{|c|}{ the number of documents } & \multicolumn{1}{c|}{ quantity } & proportion \\
\hline wife & Lo07, Lo08 & 2 & $7 \%$ \\
\hline $\begin{array}{l}\text { brother/ } \\
\text { brother and family } \\
\text { members }\end{array}$ & $\begin{array}{l}\text { Lo09, Lo10, Lo12, Lo13, Lo18, } \\
\text { Lo24, Lo21, Lo23, Lo28, Lo29 }\end{array}$ & 12 & $40 \%$ \\
\hline $\begin{array}{l}\text { son/ } \\
\text { son and family } \\
\text { members }\end{array}$ & Lo05, Lo14, Lo19, Lo25 & 4 & $13 \%$ \\
\hline family members & Lo06, Lo11, Lo26, Lo30 & 4 & $13 \%$ \\
\hline unclear & $\begin{array}{l}\text { Lo01, Lo02, Lo03, Lo04, Lo16, } \\
\text { Lo17, Lo22 }\end{array}$ & 7 & $23 \%$ \\
\hline land & Lo15 & 1 & $3 \%$ \\
\hline
\end{tabular}

Table 1: Distribution of guarantors in the Old Uighur loan contracts (Yamada 1993)

In some documents, it is recorded as män birginčä yoq bar bolsar, män inim/ oylum...birșün "If I die before I pay it back, my brother/son...pays for it". In some documents, it is recorded as män birginčä yoq bar bolsar, män inim...äwtäki-lär bilä köni birșün "If I die before I pay it back, my brother...and my family members pay for it". And in some documents, it is recorded as män birginčä yoq bar bolsar, män äwtäki-lär bilä köni birșün "If I die before I pay it back, my family members pay for it", without specifying which family member it is.

${ }^{17}$ Old Uighur documents follow the dating of Chinese zodiac, but the exact year cannot be determined from the text. 
It can be seen from Table 1 that in most Old Uighur contracts, the guarantor is assumed by the debtor's family members. There are also six loan contracts with which the debtors use their land as collateral, but it only accounts for 3\% of the total. In addition, there are also some loan contracts in which the guarantors were not explicitly written down or because over time parts of the text became lost. The cases in which the guarantor was unclear accounted for $23 \%$ of the total.

The cases in which family members acted as guarantors accounted for $73 \%$ of all the Old Uighur contractual documents. In contrast, in the Dunhuang Chinese contractual documents, in addition to family members, there was a larger proportion (about $36.2 \%$ ) of the guarantors who were not related to the debtor by blood. Instead, these guarantors could be from the same profession, the same surname of the debtor or even monks. ${ }^{18}$ This comparison reflects the fact that in most cases the position of guarantor was assumed by family members in Old Uighur contracts, showing the importance of strong relationships between family members and how prominent concepts of the family were among the Old Uighurs at that time.

Among the family members, the debtor's brother was most likely to act as the guarantor, accounting for $40 \%$ of all these contractual documents. The proportion is even higher than the proportion of sons as guarantor. It shows that in the society of Old Uighurs, brothers were very close to each other and mostly shared the ownership of property.

\section{The status and roles of male and female in the family}

In the family of Old Uighurs during the Yuan dynasty, the dominant position was held by males, while females were generally subjugated. This characteristic is fully reflected in the Old Uighur contractual documents.

First of all, it can be seen from the Old Uighur loan contracts that the debtor who signed the contract were always the master of the household. Among the 30 Old Uighur loan contracts mentioned above, there was not a single case where a woman acted as the debtor. This can indicate that the main power in the family, especially the control of property, was in the hands of men. Meanwhile, in most cases, the primary guarantor in Old Uighur loan contract was usually assumed by the brother or son of the debtor, such cases accounting for $53 \%$ of the total. It was rare for a female role such as wife, daughter or sister of a debtor to act as independent guarantors. Of the 30 loan contracts, only two, Lo07 and Lo08,

\footnotetext{
18 The detailed study can be found in Huo - Zhang (2004).
} 
were independently guaranteed by woman, and these two contracts belonged to the same person. The following is the transcription and translation of the Lo07 contract:

Lo07: ${ }^{19}$

1. küskü yïl törtünč ay bir yangïqa

2. manga bolmï̌-qa asï̀-qa kümüš

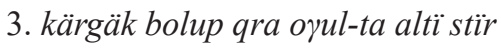

4. kümüš altïm qač ay tutsar-män ay

5. sayu birär yarïm baqïr kümüš asïy-

6. -ï bilä köni birürmän birginčä yoq

7. bar bolsar-män kišim tüzük köni

8. birzün tanuq borluqči tanuq är buqa

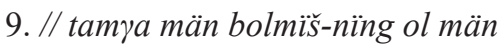

10. yï̈ïna tutung ayị̈ïp bitidim

Translation:

"On April 1, in the year of the mouse, since I, Bolmiiš, needed the silver with interest, I borrowed six stir silver from Qra O $\gamma$ ul. For how many months I keep them, I give them back with interest of one and a half baqir ${ }^{20}$ silver per month. If I'm gone, before I give it, my wife Tüzük should give it correctly.

Witness: Borluqči

Witness: Är buqa

This seal is mine, Bolmiš.

I, Yïrïna Tutung, wrote it after asking."

From the above extract, we can see that the debtor Bolmï̌ made his wife Tüzük as the guarantor of the contract. In Old Uighur loan contracts, except for one or two cases like this, there was almost no females who acted as independent debtor or guarantor, and thus the main rights of their families were still held by male.

Secondly, from the testament recorded in Old Uighur, it also can be seen that in the family of Old Uighurs, males had more power and a higher status than females. As is recorded in the following testament WP01, when the male master of the family died of illness, he often left a testament to instruct whether his wife could remarry.

19 The original transcription, Japanese and German translation can be seen in Yamada, N II (1993: 90-91).

${ }^{20}$ baqir is the unit of weight of money. 
WP01: ${ }^{21}$

1. küskü ÿ̈l säkizinč ay säkiz ygrmikä

2. män tüšiki aүïr igkä tgmiš-kä

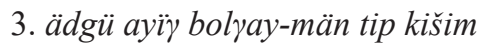

4. sïlang-qa bitig qotdum mïnta

5. kin är-kä bäg-kä tgmätin ävim-

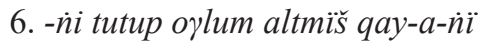

7. asïrap yorïzun....

Translation:

"On August 18, in the year of the mouse year, because I, Tüšiki, had got a serious illness, and I do not know whether I will be better or worse, I left (this) letter to my wife Silang. From now on she shouldn't go to another man (remarry), she should care for my family and look after my son Altmiš Qaya...."

Liu and Yan (2006) state that it can be seen from this document that the husband did not want his wife to remarry after his death, and clearly stated that his wife ävim-ni tutup "hold my family". That is to say, the wife was to be head of the family from then on. Although the husband's statement that he would not let the wife remarry can indicate that the wife's right to remarry, ${ }^{22}$ we hold the different opinion. Even though women had the right to remarry during the Yuan dynasty, we see wives still occupying the weaker position in the family of Old Uighurs since the husband's testament could determine the woman's right to remarry or not, clearly demonstrating that the rights and roles of men in the family remained of paramount importance. Therefore, this document also embodies the rights that males used to dominate the family in the society of the Old Uighurs at that time.

In short, from the analysis of the above two aspects, it can be seen that in the families of the Old Uighurs during the Yuan dynasty, the rights and status of men are higher than those of women. Not only is the debtor in the loan contracts usually assumed by the male master of the family, but the guarantor is also a male role in most instances. In addition, men can decide whether their wives can remarry or not. All these are proof of the characteristics of the family of Old Uighurs, that is, a patriarchal and traditional family dominated by men. The reasons for these characteristics are related to the economic situation and social system of that time. As we have mentioned before, during the $13^{\text {th }}-14^{\text {th }}$ century,

${ }^{21}$ The original transcription, Japanese and German translation can be seen in Yamada, N II (1993: 134-135).

${ }^{22}$ More explanation can be seen in Liu-Yan (2006). 
the main economic mode of the Old Uighurs was agricultural production, so men were the main labour force in the family economy and production. Such an economic system results in men having a higher position in the family than women and thus having more dominant power over the family.

\section{The phenomenon of selling and mortgaging relatives}

During the Yuan dynasty, there were all kinds of illegal and legal trade in humans among the population. Among these, the most commonly traded goods were slaves and relatives. Some of the Old Uighur contractual documents also describe this phenomenon. Some contracts were used to sell sons and other relatives, and some contracts were used to sell their sons into pawnship. In some of the Old Uighur sale contracts and mortgage contracts such as Sa26, Sa27, P101, $\mathrm{P} 102$, it can be seen that the father could freely and legally sell or mortgage his son to others, as shown in the sale contract below:
$\mathrm{Sa} 26::^{23}$
1. ...yïl üčünč ay tört yangï-
2. -qa ... qutluү tämür är tuүmïs
3. tuqdamïš olar-qa yunglaq-lïq yarmaq
4. kümüš kärgäk bolup sängäkdaz aqa-a-tïn
5. altmï̌ altun alïp mụbäräk qoč aḍlï

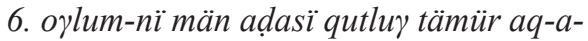
7. -sï är tuүmïs aq-a-sï tuqdamï̌ üčägü birlä

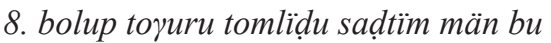
9. oүul-qa ming yïl tümän kün-kä tagï
10. sängäkdaz aq-a ärklig bolṣun....

Translation:

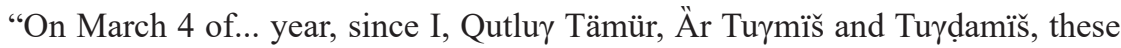
(people), needed silver to consume, I sold my son named Mụbäräk Qoč legally

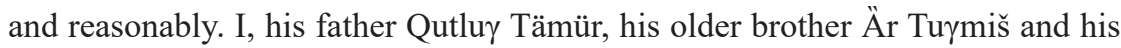
older brother Tưḍamïš, all three together, received 60 gold coins from older brother Sängäkḍaz. This son will (always) belong to the older brother Sängäkḍaz for a thousand years, ten thousand days...."

${ }^{23}$ The original transcription, Japanese and German translation can be seen in Yamada, N II (1993: 55-56). 
It is obvious that the behaviour of father and older brother in selling their son and younger brother was a common phenomenon in the Old Uighur's society at that time. In their family, the patriarch had very great power and could decide either to sell or pawn the relatives. We argue that the reasons for this phenomenon are as follows: firstly, trade in humans was a long-standing social phenomenon that had existed since the Han Dynasty and became more frequent during the Yuan Dynasty. Therefore, in this social environment, population trading also existed commonly in the Old Uighur's society in the Yuan Dynasty. Secondly, due to the frequent occurrence of wars and disasters during this period, as well as the heavy tax burden, people lived in poverty and many chose to sell and pawn their relatives. This was especially true of the youngest son who, having least ability to make an economic contribution, more acutely impacted the problems of survival faced by the whole family.

\section{Conclusion}

This paper discusses the family structure and characteristics of the Old Uighur's society in the Yuan dynasty, as reflected in the Old Uighur contractual documents. These documents show the following characteristics of the family:

Firstly, most of civilian families of Old Uighurs adopted monogamy, and the type of family structure was the extended paternal family, consisting of kin groups. In Old Uighur loan contracts, the debtor's family members, especially the brothers, played the role of the guarantor in most cases. This shows that the ties between immediate family members were strong, blood relationships being particularly important. Specifically, brothers live together and share the property of the family.

Secondly, in the family of Old Uighur's society, the rights and status of males were higher than those of females. In most of loan contracts, the debtor is usually assumed by the male master of the family, and the guarantor is also taken by a male such as a brother and or son of the debtor. In addition, when men died, they had the right to make a testament which decided whether their wives could remarry or not. The reason for this practice was that men were the main labor force in the economy and production at that time, so they occupied the dominant position in the family.

Thirdly, some Old Uighur contractual documents also reflect the phenomenon that people could sell and mortgage their relatives such as son, and this habit was very common at that time. This phenomenon is a continuation of the customs of previous dynasties. Concurrently, due to poverty, people were forced to choose this course of action to maintain their livelihood. 


\section{References}

Brose, Michael C. 2017. "The Medieval Uyghurs of the $8^{\text {th }}$ through $14^{\text {th }}$ Centuries." In: David Ludden (ed.) The Oxford Research Encyclopedia of Asian History. New York: Oxford University Press, 1-20. https://doi.org/10.1093/acrefore/9780190277727.013.232

Chen, Zongzhen 陈宗振 1996. “Woguo Tujueyu de 'Fumu Xiongzi' deng Chengwei Jiqi Yanbian” 我国突厥语的“父母兄姊”等称谓及其演变 [“The Appellation of “Father, Mother, Brother and Sister' and Its Evolution in Turkic Languages of China"]. Minzu Yuwen 民族语 文 [Minority Languages of China] 4: 71-80.

Gabain, Annemarie von 1973. Das Leben im uigurischen Königreich von Qoco (850-1250). Wiesbaden: Harrassowitz.

Geng, Shimin 耿世民 2006. Huihuwen Shehui Jingji Wenshu Yanjiu 回鹘文社会经济文书研究 [Studies of the Uighur Civil Documents]. Peking: Minzu University of China Press.

Hamilton, James 1986. Manuscrits oü̈gours du IXe-Xe siècle de Touen-Houang. Paris: Peeters.

Huo, Cunfu 霍存福 - Zhang Yan 章燕 2004. “Tulufan Huihuwen Jiedai Qiyue Yanjiu” 吐鲁番 回鹘文借贷契约研究 [On Uighur Loan Contracts Unearthed in Turfan]. Jilin Daxue Shehui Kexue Xuebao 吉林大学社会科学学报 [Jilin University Journal Social Sciences Edition] 6: 95-106.

Li, Jingwei 李经纬 1996. Tulufan Huihuwen Shehui Jingji Wenshu Yanjiu 吐鲁番回鹘文社会经 济文书研究 [Study on Uighur Social and Economic Documents in Turpan]. Urumchi: Xinjiang Renmin Press.

Li, Jingwei 李经纬 2012. Huihuwen Shehui Jingji Wenshu Jijie 回鹘文社会经济文书辑解 [Uighur Texts Concerning of Society and Economy]. Lanzhou: Gansu National Press.

Ligeti, Louis 1973. "À propos d'un document ouigour de l'époque mongole." Acta Orientalia Academiae Scientiarum Hungaricae 27.1: 1-18.

Liu, Ge 刘戈 2000. Huihuwen Qiyue Wenshu Chutan 回鹘文契约文书初探 [A Preliminary Study of Contractual Documents in Old Uighur]. Taipei: Wu Nan Publishing Company.

Liu, Ge - Kou Juxia 2006. "Elucidation of Yägän in the Contract in Uygur." In: Elena V. Boikova - Rostislav B. Rybakov (eds.) Kinship in the Altaic World: Proceedings of the $48^{\text {th }}$ PIAC. Wiesbaden: Harrassowitz Verlag, 211-217.

Liu, Ge 刘戈 - Yan Haixiong 燕海雄 2006. “Gudai Tulufan Diqu Putong Funv Zai Shehui Jingji Shenghuo zhong de Diwei - Yi Tulufan Chutu Hanwen Huihuwen Qiyue Wenshu Suojian Weili” 古代吐鲁番地区普通妇女在社会经济生活中的地位一以吐鲁番出土汉文、回鹘 文契约文书所见为例 [The Status of the Common Women in the Social Economic Life in the Ancient Turpan Areas: The Examples from the Ancient Contract Scripts in the Han and Uighur Language Discovered in Turpan]. Minzu Yanjiu 民族研究 [Ethno-national Studies] 6: 53-62.

Radloff, Wilhelm 1928. Uigurische Sprachdenkmäler. Materialien nach dem Tode des Verfassers mit Ergänzungen von S. Malov herausgegeben. Leningrad: Verlag der Akademie der Wissenschaften der USSR (Reprint: Osnabrück 1972).

Ramstedt, Gustaf John 1969. "Four Uigurian Documents." In: Carl Gustav Mannerheim (ed.) Across Asia from West to East in 1906-1908 (2). Netherlands: Humanities Press, 1-12.

Vernadsky, George 1936. "Notes on the History of the Uigurs in the Late Middle Ages." Journal of the American Oriental Society 56.4: 453-461. https://doi.org/10.2307/594268

Yamada, Nobuo 山田信夫 1965. “Uiguru bun taishaku keiyakusho no shoshiki ウイグル文貸 借契約書の書式 [The Format of the Old Uighur Loan Contracts].” Ōsakadaigaku bungaku$b u$ kiyo 大阪大学文学部紀要 [Memoirs of the Faculty of Literature Osaka University] 11: 87-216. 
Yamada, Nobuo 山田信夫 (author), Oda, Juten 小田壽典 - Zieme, Peter P ・ イーメ - Umemura, Hiroshi 梅村坦 - Moriyasu, Takao 森安孝夫 (eds.) 1993. Sammlung uighurischer Kontrakte / Uiguru bun keiyaku bunsho shūsei ウイグル文契約文書集成 [Collection of Uighur Contracts]. Osaka: Osaka University Press.

Yang, Fuxue 杨富学 1990. “Mengyuan Shidai Gaochang Huihu Tudi Zhidu Chutan” 蒙元时代高 昌回鹘土地制度初探 [A Preliminary Study on Land System of the Qocho Uighur during the Yuan Dynasty]. In: Tulufanxue Yanjiu Zhuanji 吐鲁番学研究专辑 [Turpan Studies Album] (edited by Xinjiang Research Data Center of Dunhuang Turpan Studies). Urumchi: Xinjiang Research Data Center of Dunhuang Turpan Studies Press, 279-318.

Zhang, Chengzhi 张承志 1983. “Yuandai Weiwuerren Neibu Zhuangkuang” 元代畏兀儿人内部 状况 [The Internal Conditions of the Uighur People in the Yuan Dynasty]. Minzu Yanjiu 民族 研究 [Ethno-National Studies] 5: 13-23.

Zhang, Tieshan 张铁山 - Cui, Yan 崔炎 2017. "Huihuwen Qiyue Wenshu Canyuzhe Chengwei Kaoshi - Jianyu Dunhuang Tulufan Hanwen Wenshu Bijiao” 回鹘文契约文书参与者称谓 考释一兼与敦煌吐鲁番汉文文书比较 [Interpretation of the Appellations of the Participants of Contractual Documents in Uighur Script: A Comparison with the Dunhuang Turpan Documents in Han Character]. Xiyu Yanjiu 西域研究 [The Western Regions Studies] 2: 79-84.

Zieme, Peter 1974. "Ein uigurischer Landverkaufsvertrag aus Murtuq." Altorientalische Forschungen 1: 295-308.

Zieme, Peter 1976. "Zum Handel im Uigurischen Reich von Qoco." Altorientalische Forschungen 4: 235-249. https://doi.org/10.1524/aofo.1976.4.jg.235

Zieme, Peter 1977. "Drei neue uigurische Sklavendokumente." Altorientalische Forschungen 5: 145-170. https://doi.org/10.1524/aofo.1978.5.jg.145

Zieme, Peter 1980a. "Ein uigurischer Leihkontrakt über Weizen." Altorientalische Forschungen 7: 273-275. https://doi.org/10.1524/aofo.1980.7.jg.273

Zieme, Peter 1980b. "Uigurische Pachtdokumente." Altorientalische Forschungen 7: 197-245. https://doi.org/10.1524/aofo.1980.7.jg.197

Zieme, Peter 1992. "Eine uigurische Hausverkaufsurkunde aus Qočo." Altorientalische Forschungen 19: 359-371. https://doi.org/10.1524/aofo.1992.19.2.359 
